sensory cells, Blochlinger et al. find an open reading frame encoding a large protein of nearly 2,200 amino-acid residues that also includes a homoeo domain. By generating an antiserum to part of the predicted sequence, these authors find that the protein is expressed in external sensillar nuclei but not in any of the internal sensory cells. The timing and location of cut protein suggest that it regulates other genes necessary for normal development of external sensory structures.

Insect sensory structures arise from epidermal mother cells by simple stereotyped lineages. The switch from a surface to an internal sensory structure could result from transformation of the mother cell itself, generating a new lineage, or through transformations of each of the progeny, switching them independently. Additional lineage studies could be valuable in resolving when and where the cut action occurs.

On page 151 of this issue Saint et al. ${ }^{4}$ report the cloning and sequencing of the gene rough, another Drosophila homoeobox-containing gene essential for sensory cell development. The rough mutants typically have defective compound-eye structure. Unlike other Drosophila homoeobox-containing genes, rough is not expressed during embryogenesis. The product appears during the third larval stage, when the photoreceptors become specified through a series of intercellular contacts along the advancing morphogenetic furrow of the eye disk. Saint et al. find rough messenger RNA along and behind the disk furrow as well as in the larval brain. Loss of rough function usually results in ommatidia with reduced numbers of photoreceptors. To pinpoint the role of rough function, a developmental analysis of mutant eye disks will be needed where the specific cell contacts can be resolved by electron microscopy.

A final example of a homoeobox-containing gene that is required for normal sensory neuron specification appears in a recent issue of Cell. In that study, Way and Chalfie $^{5}$ characterize the nematode gene mec-3, whose normal function is essential for the differentiation of a class of six touch-sensitive neurons. Although about 20 genes have been identified that in various ways alter the normal function of the touch cells, the mec-3 gene alone seems involved in specifying the neurons without altering the cell lineage. In lossof-function mec-3 mutants, each touch cell

1. Doe, C.Q., Hiromi. Y.. Gehring, W. \& Goodman, C.S Science 239, 17(1-175 (1988).

2. Doe C. O. Smouse D \& Goodman, C.S. Nature 333,376 $378(1988)$.

3. Blochlinger, K. Bodmer, R., Jack, J. Jan, L. Y, \& Jan, Y.N. Nature 333, 629-635(1988)

4. Saint. R.. Kalionis, B., Lockett, T.J. \& Elizur, A. Nature 334. 151-154 (1988).

5. Way, J. \& Chalfie. M. Cell 54, 5-16 (1988).

6. Awgulewitsch, A. Utset, M.F. Hart, C P. McGinnis, W. \& Ruddle. F. Nature 320, 328-335.(1986)

develops into an as-yet unidentified neuron. Furthermore normal mec-3 function is necessary for a second mutation, mec- $4(d)$, to cause touch-cell degeneration. An intriguing possibility is that the regulatory DNA of the $m e c-4(d)$ gene is bound by the mec-3 protein.

Do these examples demonstrate a general role for genes with homoeo boxes that will apply to all neurons? The answer to this question is particularly significant for understanding vertebrate genes with homoeo boxes, because many of these are expressed in the central nervous system ${ }^{6}$. Unfortunately, the evidence demonstrat-

\title{
Ruffled feathers calmed by fossil bird
}

New specimens of Archaeopteryx lithographica, the earliest known bird, are not found every day - in fact until now only five have been identified. This makes the recent announcement of a sixth especially exciting (Wellnhofer, P. Science 240, $1790 ; 1988)$. This individual had previously been assigned to the chicken-sized thero-

\section{IMAGE UNAVAILABLE FOR COPYRIGHT REASONS}

Bone of contention - Archaeopteryx, courtesy of the British Museum (Natural History).

pod dinosaur Compsognathus but now detailed preparation of the fossil has shown up impressions of the shafts of feathers.

The specimen, complete except for most of the skull, is by far the largest yet found, some 10 per cent larger than the specimen in the British Museum (Natural History) in London (see figure) and fully twice as big as that in the museum in Eichstatt, West Germany. This will lend weight to the contention that two species are represented in the collection, the five largest being A. lithographica while the Eichstatt specimen is removed to Archaeopteryx sp. or even a new genus, Jurapteryx recurva.

All Archaeopteryx specimens come from the extremely finely grained limestone of Solnhofen in Bavaria, renowned in the ing a role for the homoeo box in the nervous system is still slim, because it is difficult to examine the development of singly identified neurons, and because there are only a few systems where both detailed genetics and developmental analyses are feasible. By combining these approaches with molecular methods, as has been done with nematodes and fruitflies, it is now possible to probe deeply into the role of specific kinds of genes in the development of the nervous system. $\square$

Haig Keshishian is in the Department of Biology, Yale University, PO Box 6666. New Haven, Connecticut 06511-8112, USA.

printing industry for its evenness and quality in lithography, hence the specific name of the fossil. The new specimen was collected by the former mayor of Solnhofen, who did not realise the importance of his find until it was identified as Archaeopteryx by staff at the Eichstatt museum. The subsequent discovery of feather shaft impressions precludes any possibility that these may have been forged. In 1986, astronomers Hoyle and Wickramasinghe claimed that delicate feather prints in other Archaeopteryx specimens had been added to theropod skeletons in an elaborate museum hoax, charges strongly denied by the British Museum (Natural History). The uncharacteristically strong wording of the title of the Museum's rebuttal - "Archaeopteryx is not a forgery" - shows how high feelings were running at the time (Charig, A. J. et al. Science 232, 622; 1986).

The debate derives its intensity from the phylogenetic significance of the possession of feathers: the only character that definitively separates birds from all other groups. Because Archaeopteryx is generally considered a close relative of theropods but is relatively primitive in many features other than the possession of feathers, some researchers have suggested that feathers are a shared, derived character of birds and certain theropods. One restoration of the dinosaur Syntarsus, for example, gives it a feathery crest. But such ideas remain fanciful, as there is as yet no hard evidence to support the presence of feathers in any accredited dinosaur group. Others consider the relatively late appearance of birds in the fossil record anomalous, favouring a much earlier appearance and a relationship with early crocodiles rather than dinosaurs. Triassic fossils from Texas (Beardsley, T. Nature 322,$677 ; 1986$ ) may lend credence to this view but their identification as primitive birds has not yet met with general acceptance. Until then, playful suggestions that fossils of Compsognathus can be forged by removing feather impressions from Archaeopteryx specimens are not regarded as plausible.

Henry Gee 